\title{
Enzyme Assisted Extraction of Polyphenols from the Old Tea Leaves
}

\author{
Hai TC ${ }^{1}$, Nam ND ${ }^{1}$, Hong Anh $\mathrm{LT}^{1}$, Vu TA² and Man $\mathrm{PV}^{* 3}$ \\ ${ }^{1}$ Ho Chi Minh City University of Food Industry, Vietnam \\ ${ }^{2}$ Faculty of chemistry and food technology, Ba Ria Vung Tau University, Vietnam \\ ${ }^{3}$ Faculty of Agro and food technology, Suranaree University, Thailand
}

*Corresponding author: Man PV, Faculty of Agro and food technology, Suranaree University, Thailand, E-mail: pvman.dbv@moet.edu.vn

Citation: Hai TC, Nam ND, Hong Anh LT, Vu TA, Man PV (2016) Enzyme Assisted Extraction of Polyphenols from the Old Tea Leaves. J Nutr Health Sci 3(4): 404. doi: doi: 10.15744/2393-9060.3.404

Received Date: August 19, 2016 Accepted Date: November 22, 2016 Published Date: November 23, 2016

\begin{abstract}
Polyphenols are a main antioxidant in the old tea leaves. These bioactive compounds have been linked with a reduced of risk cardiovascular and cancer. In this study, the enzyme cellulase was used to extract phenolic compounds (polyphenols) from the old tea leaves. The parameters such as ratio of enzyme and raw materials, $\mathrm{pH}$ and time of extraction were investigated to affect on polyphenol extraction process and kinetic equation. According to our research results, the ratio of enzyme raw material was $2 \%$ at the $\mathrm{pH} 5.5$, and these samples were incubated at $50{ }^{\circ} \mathrm{C}$ in 60 minutes that gave the best extraction results. The total of phenolic content and the purity reached $85.05 \mathrm{mg}$ GAE/g dry matter and $25.65 \%$ respectively. The extraction kinetics of phenolic and the ability of cellulase enzyme extraction $\left(\mathrm{C}_{e}\right)$ rose a 1.1 times compared with the control sample, the extraction rate constant $\mathrm{k}$ changed a little and the initial extraction rate $\mathrm{v}_{\mathrm{o}}$ found no significant difference.
\end{abstract}

Keywords: Polyphenol; Enzyme cellulase; Kinetic extraction

\section{Introduction}

Tea is the most widely consumed beverage in the world and it is known for the various health benefits. In recent year, tea is not only used as fresh drink but also traditional flavor in food product [1]. Polyphenols in green tea are believed as excellent free radical scavengers. Green tea polyphenols are believed to be responsible for cancer preventive effect, and the antioxidant activity of green tea polyphenols has been in complicated as a potential mechanism [2]. The green tea phenolic compounds of highest concentration are gallic acid (GA), (-)-gallocatechin (GC), (+)-catechin (C), (-)-epicatechin (EC), (-)-epigallocatechin (EGC), (-)-epicatechin gallate (ECG), (-)-epigallocatechin gallate (EGCG), p-coumaroylquinic acid (CA), and (-)-gallocatechin-3-gallate (GCG) [1-5].

In the tea industry, the fresh tea shoot (Camellia sinensis) including $2-3$ leaves unfurled was used to make green tea products but the old tea leaves were removed as sub products [4,5]. The old tea leaves contain a lot of tannin that are the cause of bitterness in the extracts. Today, there are many previous studies on extraction of polyphenols that have been done with different methods. The most commonly solvents using for extraction are hot water and organic solvents [3]. However, enzyme assisted extraction has been successfully used for extraction from biological active compounds, especially polyphenols in ambarella fruit, Fumaria officinalis and strawberry,... but on the old tea leaves, it is still limited [6-8]. Assisted enzyme extraction helps to increase the recovery efficiency polyphenol compounds $[3,4]$. The most distinctive feature of enzymes is that they can effectively operate at mild physiological conditions, at atmospheric pressure and $\mathrm{pH}$ of 3-10 [6,9,10]. Therefore, in this study, we conducted a survey to assess the effect of cellulase to polyphenol compounds that were extracted in the old tea leaves and enhance the use of the old tea leaves in the production from this material.

\section{Materials and Methods}

\section{Materials and chemicals}

\section{Materials}

Old tea leaves were harvested from Loc Chau, Bao Loc, Lam Dong province, Viet Nam. Tea leaves were inactivated enzyme by steaming from $95^{\circ} \mathrm{C}$ to $100{ }^{\circ} \mathrm{C}$ for 5 minutes and dried from $40^{\circ} \mathrm{C}$ to $50{ }^{\circ} \mathrm{C}$ for 8 hours. Then they were crushed and stored in sealed plastic bags to avoid direct sunlight. 


\section{Chemicals}

Folin - Ciocalteu agent and Gallic acid were purchased from Merck, methanol (Aldrich - Sigma) $\mathrm{Na}_{2} \mathrm{CO}_{3}$, ethanol (China).

Cellulase (Cellulase 1.5L) was derived from Trichoderma reesei and manufactured by Novo Nordisk Ferment (Switzerland). It has an activity of $700 \mathrm{EGU} / \mathrm{g}$ with a density of $1.22 \mathrm{~g} / \mathrm{ml}$.

\section{Methods}

Preparation the polyphenol extracts: Dried old tea leaves were crushed to $0.5-1.0 \mathrm{~mm}$, and $50 \mathrm{~g}$ of old tea leaves were used in each assay. The samples were placed into $1000 \mathrm{~mL}$ flasks. The obtained dried tea leaves were mixed with water at the weight ratio of 1:15 preparing for extraction.

\section{Extraction process}

Effect of enzyme concentration on the extraction of polyphenols: Enzyme cellulase was added into the flask with different concentrations. The enzyme concentrations were changed between $0,0.5,1,1.5,2$ and $2.5 \% \mathrm{v} / \mathrm{w}$, and incubated at $40{ }^{\circ} \mathrm{C}$ in 20 minutes at $\mathrm{pH}$ 4.5. After that, cellulase in these mass extracts was inactivated at $90{ }^{\circ} \mathrm{C}$ in 5 minutes. The control sample (without enzyme assisted extraction) was conducted extraction at $90^{\circ} \mathrm{C}$. Then the mass extractions were carried out to centrifugation at $3500 \mathrm{rpm}$ in 10 minutes.

Effect of $\mathbf{p H}$ on the extraction of polyphenols: The $\mathrm{pH}$ was surveyed at different values, its values including 3.5, 4.5, 5.5, 6.5, 7.5 and these samples were incubated at $40^{\circ} \mathrm{C}$ in 20 minutes. The enzyme concentration was optimized from the experiment above. Then enzyme in these mass extract was inactivated at $90^{\circ} \mathrm{C}$ in 5 minutes.

Effect of enzymatic treatment time on the extraction of polyphenols: Time treatment was changed in $0,20,40,60,80$ and 100 minutes. The enzyme concentration and $\mathrm{pH}$ were optimized from the experiments above. Then enzyme in these mass extract was inactivated at $90^{\circ} \mathrm{C}$ in 5 minutes.

\section{Total polyphenols determination (TP)}

Folin-ciocalteu method, is one of several methods which are used to determine total polyphenols. Polyphenols reduce Folin agent (yellow solution of polyphosphatetungstenate and molydate) in mild base medium to form deep blue color $[3,11]$. The total polyphenol level (TP): was evaluated by spectrophotometric method using Folin-Ciocalteu reagent at 765 nm [3,11]. The results were expressed as the equivalent to mg of gallic acid per litre of extract (mg GAE/L).

The total polyphenol purity: The crude TP was dynamically adsorbed on a glass column packed with AB- 8 resin. Based on the result of the static AB-8 resin adsorption experiments, the equilibrium time was chosen as $4 \mathrm{~h}$. Distilled water was first used to remove sugars, acids and other water-soluble compounds. Then, the crude PP was eluted with ethanol at a constant flow velocity of $1.5 \mathrm{~mL} / \mathrm{min}$, and two bed volumes (BV) of phenolic eluent was collected and concentrated in a rotary evaporator to afford the purified PP. The total polyphenol purity (PP) in the mash extraction wass calculated by the ratio of the weight of purified polyphenols in mash extraction and the total solids weight $(\mathrm{g})$.

$$
\text { Polyphenol purity }(\mathrm{PP})=\frac{m_{\mathrm{PP}} \times 100}{m_{\mathrm{CKD}}}(\%)
$$

\section{Whereas:}

- $\mathrm{m}_{\mathrm{pp}}$ : the weight of purified polyphenol in the mass extraction $(\mathrm{g})$.

- $\mathrm{m}_{\mathrm{CKD}}$ : the total solids weight $(\mathrm{g})$.

\section{Catechins determination}

Catechins were measured using HPLC method described in previous literature with modified [5,9]. Analyses were performed on an HPLC 1100 Agilant, with C18 column (Synergi Hydro-RP 80R, Phenomenex, US) and UV detector (230 nm). Eluent A was acetonitril $(\mathrm{ACN})$ and eluent $\mathrm{B}$ was $0.1 \%$ aqueous phosphoric acid, the flow rate was kept constant throughout the analysis at 1 ml. min-1.

\section{Determination of kinetic parameters of the polyphenol extraction}

To determine the extraction rate constant of the antioxidants, the second-order rate law was applied [2]. The general second-order model can be written as:

$$
\frac{\mathrm{d} C_{\mathrm{t}}}{\mathrm{dt}}=\mathrm{k} \cdot\left(\mathrm{C}_{\mathrm{e}}-\mathrm{C}_{\mathrm{t}}\right)^{2}
$$


Where: $\mathrm{k}$ is the second-order extraction rate constant (L/g.min), $\mathrm{C}_{\mathrm{e}}$ is the extraction capacity (the equilibrium concentration of antioxidants in the extract) $(\mathrm{g} / \mathrm{L})$, and $\mathrm{C}_{\mathrm{t}}$ is the concentration of the extract at a given extraction time $(\mathrm{g} / \mathrm{L})$.

The integrated rate law for a second-order extraction, under the boundary conditions $t=0$ to $t$ and $C_{t}=0$ to $C_{t}$, can be written as an equation (3) or a linearized equation (4):

$$
\begin{gathered}
\mathrm{C}_{\mathrm{t}}=\frac{\mathrm{C}_{\mathrm{e}}^{2} \cdot \mathrm{k} \cdot \mathrm{t}}{1+\mathrm{C}_{\mathrm{e}} \cdot \mathrm{k} \cdot \mathrm{t}} \\
\frac{\mathrm{t}}{\mathrm{C}_{\mathrm{t}}}=\frac{1}{\mathrm{k} \cdot \mathrm{C}_{\mathrm{e}}^{2}}+\frac{\mathrm{t}}{\mathrm{C}_{\mathrm{e}}}
\end{gathered}
$$

The initial extraction rate, $\mathrm{v}_{\mathrm{o}}(\mathrm{g} / \mathrm{L} . \mathrm{min})$, as $\mathrm{C}_{\mathrm{t}} / \mathrm{t}$ when $\mathrm{t}$ approaches 0 , can be defined as equation:

$$
\mathrm{v}_{\mathrm{o}}=\mathrm{k} \cdot \mathrm{C}_{\mathrm{e}}^{2}
$$

\section{Statistical analysis}

All experiments were performed in triplicate. Means were compared by multiple range tests with $\mathrm{p}<0.05$. Analysis of variance was done to use the software Statgraphics plus centurion XVI. Optimization parameters were used by software Modde 5.0.

\section{Results and Discussion}

\section{Effect of enzyme concentration on the extraction of polyphenols}

Enzyme was employed in the experiment because it is non-toxic and a green solvent. The result on Figure 1 showed that the sample was untreated with enzyme, the total polyphenol level achieved at $58.75 \mathrm{mg}$ GAE/g dry matter. It was lower than that of these samples which were treated with enzyme. When enzyme concentration increased from $0.5 \%$ to $2.5 \%$, the total polyphenol content and the purity of polyphenol in mass extracts increased dramatically. The maximum total polyphenol content (TP) achieved at $74.45 \mathrm{mg} \mathrm{GAE} / \mathrm{g}$ and $25.39 \%$ of polyphenol purity at $2 \% \mathrm{v} / \mathrm{w}$ of enzyme concentration. It was higher $22.99 \%, 21.3 \%$ and $12.99 \%$ than that of the samples treated with enzyme at $0.5 \%, 1 \%$ and $1.5 \% \mathrm{v} / \mathrm{w}$. However, when the cellulase concentration increased to $2.5 \% \mathrm{v} / \mathrm{w}$, the total polyphenol level and the purity of polyphenol decreased slightly and insignificantly to compare with the sample that was treated at $2 \% \mathrm{v} / \mathrm{w}$. The reason for this may be that as more amount of enzyme is added, the more cell wall polysaccharides are hydrolyzed, especially the linkage between polysaccharide-lignin network that released more amount of polyphenol compounds $[6,10,12]$. Another mechanism may be the direct enzyme catalyzed breakage of the ether and ester linkages between phenol and plant cell wall polymers $[7,8,13,14]$. According to Yang-Hee Hong, et al. the total polyphenol level increased $4.25 \%$ when using cellulase to assist extraction (from $2.35 \mathrm{mg} / \mathrm{ml}$ to $2.45 \mathrm{mg} / \mathrm{ml}$ ) [14].

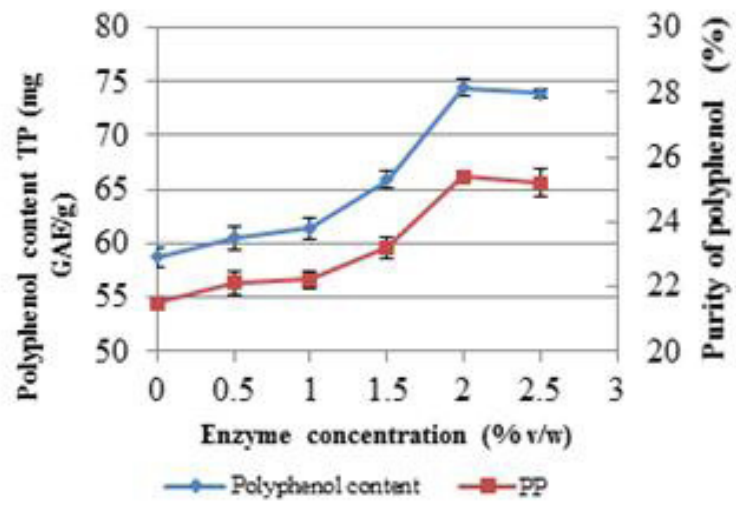

Figure 1: Effects of cellulase concentration on the polyphenol level and the purity of polyphenol on the tea leaves mash extract

\section{Effect of $\mathrm{pH}$ on the extraction of polyphenols}

Polyphenols concentration in the extracts was rapidly decreased when increased $\mathrm{pH}$ value from 3.5 to 7.5 (Figure 2). At pH 3.5, the maximum total polyphenol level in mass extract was $76.76 \mathrm{mg} \mathrm{GAE} / \mathrm{g}$ and the lowest polyphenol concentration at pH 7.5 (64.95 $\mathrm{mg} \mathrm{GAE} / \mathrm{g})$. There was insignificantly the total polyphenol level in the mass extract when $\mathrm{pH}$ of the extraction achieved at 3.5, 4.5 and 5.5 each $(\mathrm{P}>0.05)$. Its value decreased to $9.19 \%$ when increasing $\mathrm{pH}$ from 6.5 to 7.5 (71.52 mg GAE/g to $64.95 \mathrm{mg} \mathrm{GAE} / \mathrm{g})$.

The purity of polyphenols in the mass extract did not similar trend with the recovery of polyphenol content in the mass extract. The highest purity of polyphenol level got a peak at $\mathrm{pH} 5.5(23.31 \%)$ then it reduced when increasing pH value from 6.5 to 7.5 (22.29\% and $20.49 \%$ respectively). 


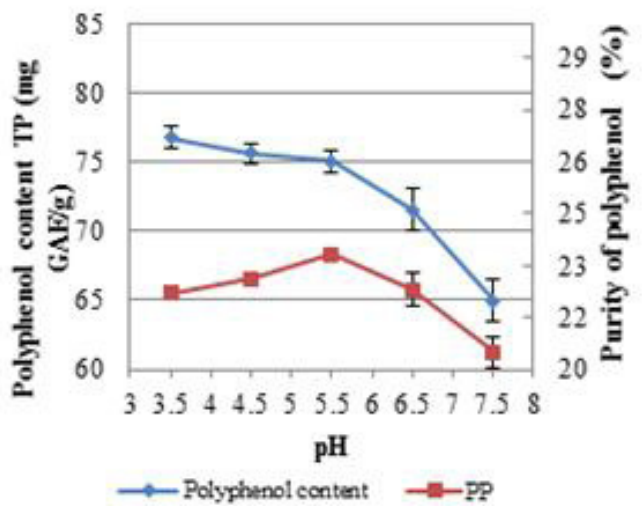

Figure 2: Effects of $\mathrm{pH}$ concentration on the polyphenol level and the purity of polyphenol on the tea leaves mash extract

The reason of this trend could be explained by the $\mathrm{pH}$ optimum of cellulase at $\mathrm{pH} 4.5$ [9-11]. According to Karan Vasisht, et al. $\mathrm{pH}$ affects to stability of cellulase on extraction polyphenol from the bud tea and polyphenol compounds in the mass extraction, at $\mathrm{pH}$ $1.2,2.0$ and 4.0 , its value reduced to $2.6 \%, 2.7 \%$ and $2.7 \%$ each to compare with $\mathrm{pH} 5.0[9,10]$.

\section{Effect of enzymatic treatment time on the extraction of polyphenols}

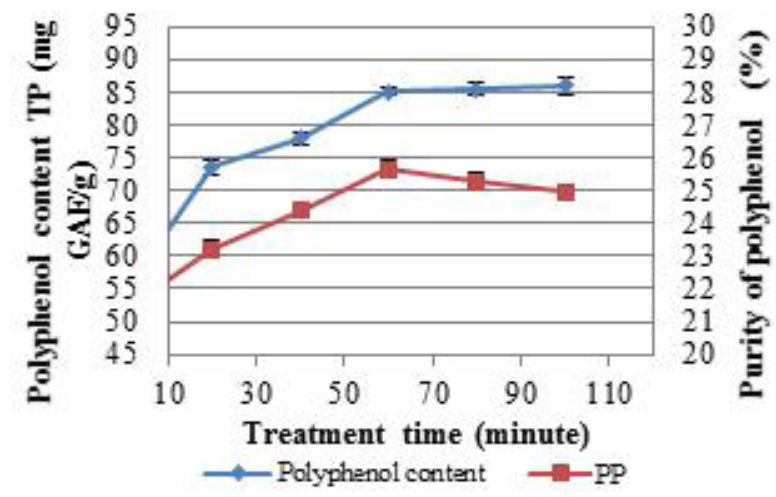

Figure 3: Effect of extraction time to phenolic content and phenolic purity

Polyphenol concentration in the extracts increased rapidly when increasing time treatment (Figure 3). The treatment time was 60 minutes, the total polyphenol content reached at $85.05 \mathrm{mg} \mathrm{GAE} / \mathrm{g}$, its value increased 1.58 times and 1.56 times to compare with these samples that were treated at 10 minutes, 20 minutes respectively. The purity of polyphenol in the mass extract also increased and reached the maximum value at 60 minute extraction, it's about $25.65 \%$. This value reduced slightly when the extraction time over 60 minutes. Longer enzyme treatment time generated high level of hydroxyl radical in the presence of oxygen that lead to a negative impact on the purity of polyphenol. Furthermore, longer enzyme treatment time effects to polyphenol purity through releasing amount of reduced sugar and insoluble protein in the mass extract $[2,3]$.

\section{Determination of kinetic parameters of the enzyme-assisted extraction from second-order kinetic model}

The result in figure 4 showed that the kinetic parameters including extraction capability $\left(\mathrm{C}_{\mathrm{e}}\right)$, extraction rate constant $(\mathrm{k})$ and the initial extraction rate $\left(\mathrm{v}_{\mathrm{o}}\right)$ changed and differed between these samples with assisted extraction by cellulose and non-enzyme assisted extraction. The extraction capability of sample with cellulase assisted extraction achieved at 89,300 mg/g and it's higher nearly 1.1 times than that of these samples without assisted enzyme $(82,874 \mathrm{mg} / \mathrm{g})$. It proved that cellulase supported for phenolic extraction, two parameters: the extraction rate (k) and the initial extraction rate changed but insignificant (Table 1) (Figure 4).

\begin{tabular}{|c|c|c|c|}
\hline Sample & $\begin{array}{c}\text { Extraction capability } \\
\mathbf{C}_{\mathbf{e}}(\mathbf{m g} / \mathbf{g})\end{array}$ & $\begin{array}{c}\text { The initial extraction } \\
\text { rate }_{\mathbf{o}}(\mathbf{m g} / \mathbf{g} \cdot \mathbf{m i n})\end{array}$ & $\begin{array}{c}\text { Rate of } \text { extraction } \boldsymbol{k} \\
(\mathbf{g} / \mathbf{m g} . \mathbf{m i n})\end{array}$ \\
\hline $\begin{array}{c}\text { Enzyme assisted } \\
\text { treatment }\end{array}$ & $82.874 \pm 0.398^{\mathrm{a}}$ & $0.005 \pm 0.0002^{\mathrm{a}}$ & $34.352 \pm 1.180^{\mathrm{a}}$ \\
\hline $\begin{array}{c}\text { Without enzyme } \\
\text { assisted treatment }\end{array}$ & $89.300 \pm 1.393^{\mathrm{b}}$ & $0.003 \pm 0.0004^{\mathrm{b}}$ & $30.520 \pm 2.096^{\mathrm{a}}$ \\
\hline
\end{tabular}

*Values with different letters in the same column are not significantly different at the level of $p=0.05$

Table 1: The kinetics parameters of phenolic compounds in the mass extraction process from the old tea leaves 


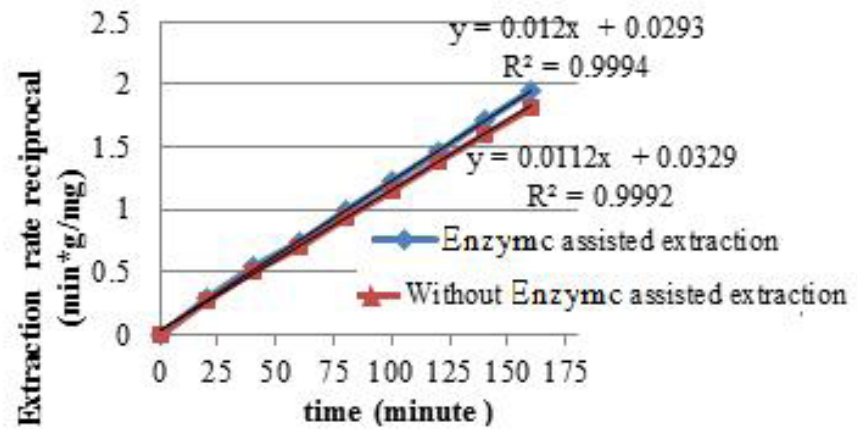

Figure 4: Extraction rate reciprocal $\left(\mathrm{t} / \mathrm{C}_{\mathrm{t}}\right)$ of polyphenol at different extraction times $(\mathrm{t})$ in enzyme-assisted extraction

Similar kinetic parameters were recently reported by Tuyen T, et al. and Le, et al. for polyphenol extraction from Ambarella fruit and grape fruit. However, the values and the increase in the kinetic parameters estimated by these authors were much lower than those in our study.

\section{Comparison catechin compounds in the old tea leaves extract with enzyme assisted extraction and non- enzyme assisted extraction}

We analyzed catechin compounds in the mass extracts by reversed phase HPLC. And the results showed that the catechin compounds in the old tea leaves were extracted by enzyme accounted for $14.52 \%$ dried weight (Table 2). It was higher than that of the control sample (without enzyme assisted extraction). C, EC, EGCG and ECG in the mass extracts with enzyme treatment were $45.7 \%, 2.73 \%, 10.87 \%$ and $40.05 \%$ higher than these catechin compounds without enzyme assisted extraction.

\begin{tabular}{|c|c|c|c|c|c|}
\hline \multirow{2}{*}{} & \multicolumn{4}{|c|}{ Catechin (\% dried weight) } & \\
\cline { 2 - 6 } & $\mathrm{C}$ & $\mathrm{EC}$ & $\mathrm{EGCG}$ & $\mathrm{ECG}$ & Total \\
\hline $\begin{array}{c}\text { Enzyme assisted } \\
\text { treatment }\end{array}$ & 0.94 & 1.83 & 9.01 & 2.74 & 14.52 \\
\hline $\begin{array}{c}\text { Without enzyme } \\
\text { assisted treatment }\end{array}$ & 0.51 & 1.78 & 8.03 & 1.63 & 11.85 \\
\hline
\end{tabular}

Table 2: Analytical catechin compounds of tea extracts

Therefore, enzyme should be used as a main method for extraction.

\section{Conclusion}

Cellulase enzyme had the positive influence to extraction polyphenols in the old tea leaves mass. Phenolic concentration increase $7.73 \%$ to compare with raw materials not using cellullase enzyme supporting extraction. Optimal conditions of processing when using cellulase to assist extraction including: the ratio of cellulase and raw materials was $2 \%(\mathrm{v} / \mathrm{w})$, $\mathrm{pH} 5.5$, and extraction processing was conducted at $50{ }^{\circ} \mathrm{C}$ in 60 minutes. Meanwhile, phenolic concentration obtained $85.05 \mathrm{mg}$ GAE/g and its purity was $25.65 \%$.

The dynamic of cellulase assisted extraction showed that the extraction ability $\left(\mathrm{C}_{\mathrm{e}}\right)$ increased 1.1 times higher than sample with non-enzyme assisted extraction, extraction rate constant $(\mathrm{k})$ changed but not significantly, and the initial extraction rate $\left(\mathrm{v}_{\mathrm{o}}\right)$ had no difference $(\mathrm{P}>0.05)$.

\section{References}

1. Grant P, Dworakoska D (2009) Tea and Diabetes: real laboratory and the real world. In Tea in Health and Disease Prevention. Chapter 55.

2. Lee LS, Lee N, Kim YH, Lee CH, Hong SP, et al. (2013) Optimization of Ultrasonic Extraction of Phenolic Antioxidants from Green Tea Using Response Surface Methodology. Molecules 18: 13530-45.

3. Pasrija D, Anandharamakrishnan C (2015) Techniques for Extraction of Green Tea Polyphenols: A Review. Food Bioprocess Technol 8: 935-50.

4. Koiwai H, Masuzawa N (2006) Extraction of catechins from green tea using ultrasound. Proc Symp Ultrason Electron 27: 483-4.

5. Trung KG, Thanh HN (2013) The influence of source material to the basic chemical composition of tea varieties midland. J Sci Development 11: $373-9$.

6. Nguyen T, Thanh T (2014) Preparations application enzyme pectinase solution extraction ambarella fruit rich in antioxidant compounds. Master's thesis Encyclopedic University.

7. Rakotondramasy-RL, Haveta JL, Portea C, Fauduetb H (2007) Solid-liquid extraction of protopine from Fumaria officinalis L.-Analysis determination, kinetic reaction and model building. Separation Purification Technol 54: 253-61.

8. Joubert E (1990) Effect of batch extraction conditions on extraction of polyphenols from rooibos tea (Aspalathus linearis). Int J Food Sci Technol 25: 339-43.

9. TCVN (ISO 14502-1:2005) (2013) Tea-Determination of substances characteristic of green tea and black tea part 1: the total Polyphenol Content In Tea-Color Measurement Method Using Reagents Folin-Ciocalteu. Chief author 9745-1. 
10. Ngoc TN, Phuoc HP, Ngoc OH (2015) Optimizing the extraction conditions of phenolic compounds from fresh tea shoot. J Food Nutr Sci 3: 106 -10.

11. Son Vu Hong, Tu Ha Duyen (2009) The research of extracting polyphenols from green tea. Part1: the factors affecting the process of quoting li polyphenols. J Sci Technol 47: 81-6.

12. Fu L, Bo-Tao X, Xuc XR, Gana RY, Zhanga Y (2011) Antioxidant capacities and total phenolic contents of 62 fruits. Food Chem 129: $345-50$.

13. Saxena M, Saxena J, Pradhan A (2012) Flavonoids and phenolic acids as antioxidants in plants and human health. Int J Pharm Sci Rev Res 16: 130-4.

14. Yang-Hee H (2013) Enzymatic improvement in the polyphenol extractability and antioxidant activity of green tea extracts. Biosci Biotechnol Biochem 77: 22-9.

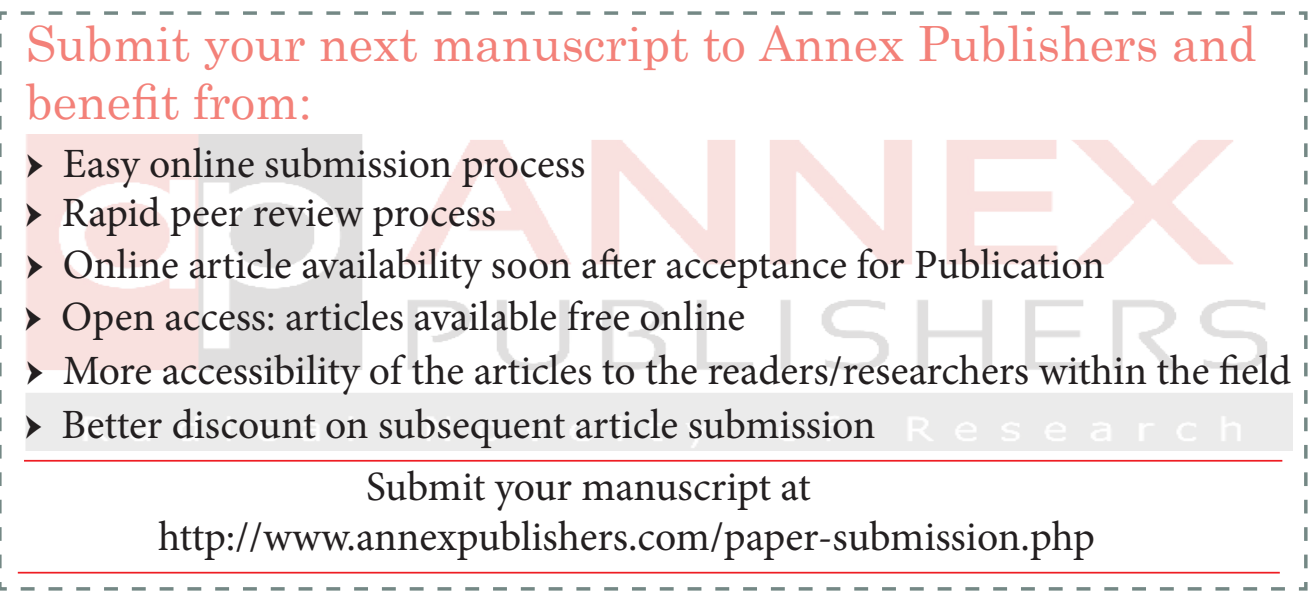

